SCIDiC

\section{Prevalence of Periodontitis In Patients using Removable Orthodontic Appliance}

Research Article

Sandhya $\mathrm{A}^{1 *}$, Nashra Kareem², Senthil Murugan $\mathrm{P}^{3}$

${ }^{1}$ Intern, Saveetha Dental College and Hospitals, Saveetha Institute of Medical and Technical Sciences(SIMATS), Saveetha University, Chennai 600 077, Tamil Nadu, India.

${ }^{2}$ Senior Lecturer, Department of Periodontics, Saveetha Dental College and Hospitals, Saveetha Institute of Medical And Technical Sciences (SIMATS), Saveetha University, Chennai 600 077, Tamil Nadu, India.

${ }^{3}$ Associate Professor, Department of Oral and Maxillofacial Surgery, Saveetha Dental college and Hospital,Saveetha Institute of Medical and Technical Sciences (SIMATS), Saveetha University, Chennai, India.

\title{
Abstract
}

Removable appliances should be considered as a method of interceptive orthodontic treatment and is mostly used in the mix dentition period. It basically either resolves the imminent dental problem or diminishes its severity. The relationship between orthodontic procedures and periodontal status is considered a challenge, especially periodontal health during and after orthodontic treatment. The aim of this study was to evaluate the prevalence of periodontitis in patients using removable orthodontic appliances. The study was conducted in a university set up sample consisting of all patients who underwent removable orthodontic treatment from June 2019 - April 2020, were examined and included in our data collection. A total of 315 case sheets were reviewed. The statistical analysis was done using SPSS software. The data was analysed using a chi-square test. It was observed that more number of periodontitis patients belonged to the age group above 30 years followed by 19 to 30 years and this was statistically significant (p-value: $0.000<0.05$ ). Within the limits of the study, it can be concluded that only $1.91 \%$ of patients using removable orthodontic appliances, had periodontitis. Further research studies with long-term follow ups in older age groups are required to periodically emphasise the importance of oral health in patients undergoing removable orthodontic treatment in order to maintain a healthy periodontium.

Keywords: Age; Gender; Periodontitis; Removal Orthodontic Appliances.

\section{Introduction}

Orthodontics is a dental specialty which aids in correction of the alignment of teeth, with respect to the skeletal form, and softtissue relationship of the patient undertaking the treatment. Removable appliances take a considerable share in contemporary orthodontic treatments. The appliance was the innovation of George Crozat, in the early 1900s. It was later more developed in European countries, but had fewer roles in the mainstream of the United States orthodontics. Instead, American orthodontists tended to use almost exclusively fixed appliances. In fact, Europeans pioneered the functional application of removable appliances for growth modification, at large [1] These appliances would resolve minor to mild dental problems or can reduce the length of fix treatment, at least. However, the key success of treatment is the patient compliance with the appliance [2]. The looseness and soft tissue irritation of the gadget would definitely reduce the success rate of treatment.

The entire periodontium, including osseous and soft tissue components, remodels with orthodontic tooth movement [3]. However, the presence of periodontal inflammation may inhibit remodeling and compromise the outcome of treatment through the loss of periodontal connective tissue attachment [4]. While some studies have shown periodontal changes induced by orthodontic appliances are transient and do not result in permanent attachment loss, 6 other studies suggest up to $10 \%$ of past orthodontic patients have greater periodontal connective tissue attachment

*Corresponding Author:

Sandhya A,

Intern, Saveetha Dental College and Hospitals, Saveetha Institute of Medical and Technical Sciences(SIMATS), Saveetha University, Chennai 600077 , Tamil Nadu, India. Tel: 9042485699

E-mail: sandhyasan37@gmail.com

Received: September 01, 2019

Accepted: September 22, 2019

Published: September 25, 2019

Citation: Sandhya A, Nashra Kareem, Senthil Murugan P. Prevalence of Periodontitis In Patients using Removable Orthodontic Appliance. Int J Dentistry Oral Sci. 2019;S1:02:004:1822. doi: http://dx.doi.org/10.19070/2377-8075-SI02-01004

Copyright: Sandhya $\mathbf{A}^{\odot}$ 2019. This is an open-access article distributed under the terms of the Creative Commons Attribution License, which permits unrestricted use, distribution and reproduction in any medium, provided the original author and source are credited. 
loss than the general population [5].

Up to now, fixed orthodontic treatment is still the best choice for the various types of malocclusions [6]. Traditional metal stents are often recommended for patients with severe occlusion or corrective problems. Although the efficacy of the traditional braces has been recognized all over the world, it still has some disadvantages. For example, wearing traditional braces will make people feel uncomfortable, and it is difficult to do conventional cleaning. Patients must carefully brush each bracket and floss around the wires to remove all traces of plaque, in order to reduce the risk of demineralization during this treatment [7]. In addition, it isfound that regular adjustments can be uncomfortable and inconvenient, which will seriously hampers proper oral hygiene, creates numerous plaque retention sites and then potentially leading to develop white spot lesions, caries, and periodontitis. Some previous studies have found that treating with fixed orthodontic appliances will stimulate the growth of a subgingival plaque, thus leading to some adverse effects, and then increase the discomfort of those patient [8-10]. Therefore, using an alternative removable orthodontic appliances may allow those patients to maintain an adequate oral hygiene, and then reduce the risk for negative dental and periodontal complications [11].

The Invisalign system (Align Technology, Santa Clara, CA), a new generation of removable, clear semi elastic polyurethane aligners, was first introduced into orthodontics in 1999 [12]. It based on a polymer composed by a chain of organic units joined with urethane links and are made from a thin, transparent plastic that fits over the buccal, lingual/palatal, and occlusal surfaces on the teeth, which was formerly a computer designedand could gradually move the teeth into an ideal position [12]. It is not permanently bonded to teeth the way traditional braces, and can be easily removed for cleaning.

Indeed, invisalign aligners can just be switched at home for a more convenient adjustment experience. It may be an option for most patients with mild to moderate bite or alignment problems. At present, many scholars believe that the invisalign aligners are more beneficial to maintain the periodontal health than the traditional fixed appliances. However, the Invisalign system usually requires those patients to spend a minimum of 20 hours per day to wear the aligners, and remove it only at eating, drinking, tooth brushing, or flossing [13]. Because the surfaces of the teeth are fitted over, it is possible to cause periodontal damage due to improper cleaning of the oral cavity and the unsmooth edge of the appliances.

In recent years, a large number of studies [14-17] about the periodontal health status in patients undergoing orthodontic treatment with fixed appliances and invisalign had been carried out. Previously our team has conducted numerous clinical trials, few review papers and surveys [18-32]. The main aim of this study was to evaluate the prevalence of periodontitis in patients using removable orthodontic appliances.

\section{Materials and Method}

\section{Study setting and sampling}

This study is a single-center retrospective study, carried out in the Department of Orthodontics in a private dental college. The study was approved by the ethical board of Saveetha dental college - Institutional ethical committee [IEC] (SDC/SIHEC/2020/ DIASDATA/0619-0320) and was in accordance with the ethical standards that were stipulated. All available records of Orthodontic patients from June 2019 - April 2020, were examined and included in our data collection. A total of 315 patients had undergone removable orthodontic appliances and were included in our study. To carry forward with our study, each patient's periodontal status was evaluated from the hospital digital database. Inclusion criteria - removable orthodontic appliance patients with Localised chronic periodontitis and generalised chronic periodontitis. Cross verification of data for error was done by presence of additional reviewers and by photograph evaluation. Simple random sampling was done to minimise sampling bias. It was generalised to the south indian population. Two examiners were involved in the study.

\section{Data collection/Tabulation}

Acquisition of data was done from the hospital digital database which records all patients details. The data were entered in the system in a methodical manner. For this study, data on the number of Removable orthodontic appliance patients and clinical variables such as their gender, age and their periodontal status were collected. The data was then entered in excel manually and imported to SPSS for analysis. Incomplete or censored data were excluded from the study.

\section{Statistical analysis}

Descriptive statistics were used to summarise the demographic information of the patients included in this study and for the acquisition of frequency distribution of the data. The statistical analysis was done using SPSS software (SPSS version 21.0, SPSS, Chicago II, USA). The data was analysed using a chi-square test to evaluate the associations of independent variables involved in the study. The p-value of less than 0.05 was considered to be statistically significant.

\section{Results and Discussion}

Out of 315 patients it was found that only 8 patients had periodontitis. The highest number of removable orthodontic appliance patients belonged to the age group of $19-30$ years $(68.47 \%)$ followed by the age group above 30 years (17.20\%), 18 years and below $(14.33 \%)$ [Figure 1]. It was observed that more number of female patients $(52.55 \%)$ use removable orthodontic appliances when compared to male patients $(47.45 \%$ ) [Figure 2]. It was observed that only $1.91 \%$ of removable orthodontic appliance patients have periodontitis. [Figure 3] More number of patients with periodontitis belonged to the age group above 30 years. The highest number of patients were without periodontitis and belonged to the age group of 19-30 years. Patients without periodontitis were more predominant among the age group of 1930 years when compared to patients with periodontitis. [p-value: 0.000 ( $\mathrm{p}$-value $<0.05$; hence statistically significant)] [Figure 4]. It is observed that periodontitis was more prevalent among females than males. Patients without periodontitis, were more predominant among females, when compared to patients with periodontitis. [p-value: 0.484 ( $p$-value $>0.05$; hence statistically non signifi- 
cant)] [Figure 5].

Several studies have addressed the impact of fixed, removable, and myofunctional orthodontic/orthopaedic appliances or retainers in relation to supragingival plaque accumulation and gingivitis [33]. These supragingival conditions are reversible a few months after appliance removal in patients with a good standard of oral hygiene. Alexander (1991) and Atack et al., (1996) suggested that orthodontic appliance removal leads to similar periodontal conditions to those observed before treatment $[34,35]$. Conflicting results comparing the periodontal status of subjects treated with fixed vs removable appliances have also been reported.

Tuncer and Baylas [36] found significant differences in probing pocket depth between removable and fixed appliances after 1 month of treatment. However, Årtun et al. [37] found no differ- ences in periodontal indices between fixed and removable orthodontic appliances. In addition, studies have [38] compared subgingival plaque levels in patients using fixed or removable appliances and reported that although plaque levels in both treatment groups were higher than that of controls, no statistically significant differences in the levels of subgingival plaque were found between the treatment groups. A study by karkhanechi concluded that Treatment with removable aligners was associated with improved periodontal status as evidenced by decreased plaque levels, gingival inflammation, bleeding upon probing, probing pocket depths, and BANA scores [39].

The effect of orthodontic appliances on periodontal health has been evaluated in many studies. Despite the widespread use of fixed and Invisalign systems, there is still an absence of evidence to determine the effect on both types of appliances on the peri-

Figure 1. This Bar chart depicts the frequency of age wise distribution based on number of removable orthodontic appliance patients. $\mathrm{X}$ axis denotes age of the patients and $\mathrm{Y}$ axis denotes the number of using removable orthodontic appliance patients. The highest number of removable orthodontic appliance patients belonged to the age group of 19-30 years (Green) followed by the age group above 30 years (Orange) and below 18 years (purple).

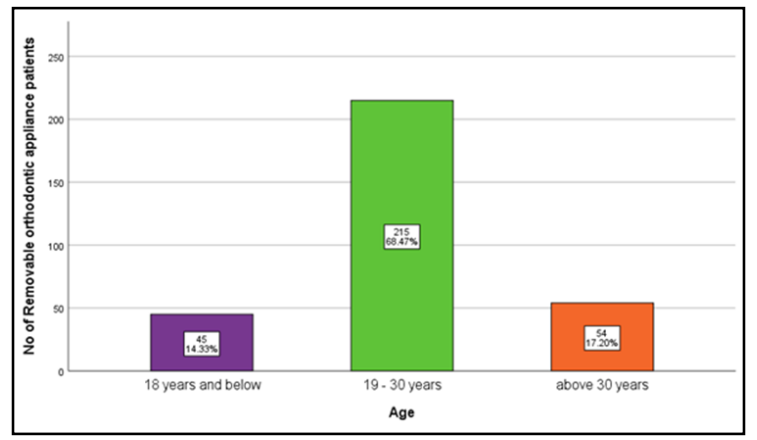

Figure 2. This Bar chart depicts the frequency of gender wise distribution of removable orthodontic appliance patients. $\mathbf{X}$ axis denotes the gender of the patients and $\mathrm{Y}$ axis denotes the number of removable orthodontic patients. It was observed that more number of female patients (red) use removable orthodontic appliances when compared to male patients (blue).

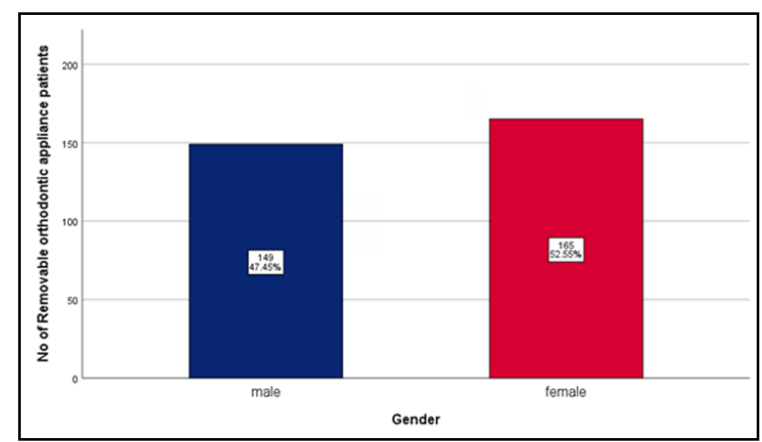

Figure 3. This Bar chart depicts the frequency of periodontal status in patients with removable orthodontic appliances. $\mathrm{X}$ axis denotes periodontal status of the patients and $\mathrm{Y}$ axis denotes the number of removable orthodontic patients. It was observed that only $1.91 \%$ of removable orthodontic appliance patients had periodontitis (Yellow).

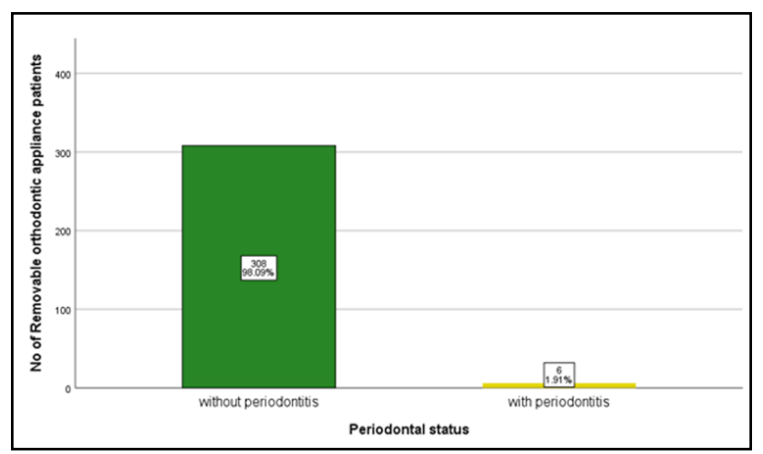


Figure 4. This Bar chart represents the association between age and periodontal status of removable orthodontic appliance patients. $\mathrm{X}$ axis denotes age of the patients and $\mathrm{Y}$ axis denotes the number of removable orthodontic patients. Inference: Patients without periodontitis (green) were more predominant among the age group of 19-30 years when compared to patients with periodontitis (yellow). Chi-Square test, p-value: 0.000 (p- value $<0.05$ ); hence statistically significant.

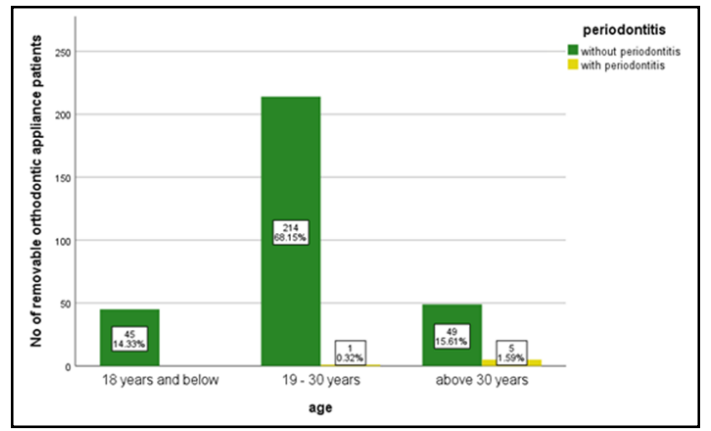

Figure 5. This Bar chart represents the association between gender and periodontal status of removable orthodontic appliance patients. $\mathrm{X}$ axis denotes the gender of the patients and $\mathrm{Y}$ axis denotes the number of removable orthodontic appliance patients. It is observed that periodontitis was more prevalent among females than males. Chi-Square test, $p$-value: 0.484 (p value $>0.05$ ); hence statistically non significant).

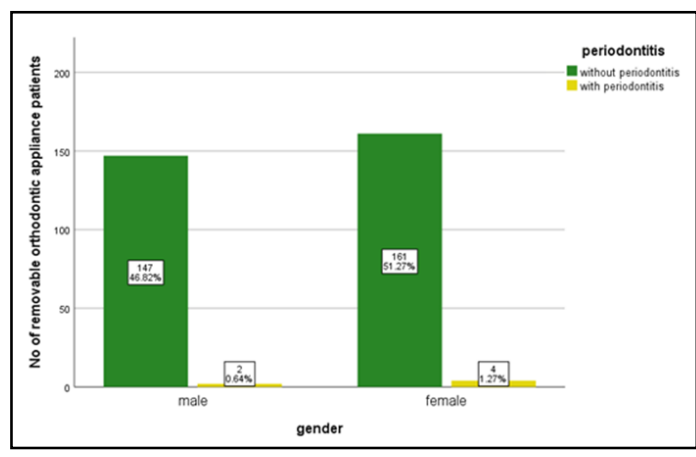

odontal. McGuinness [40] and other researchers by conducting a systematic review and a review of the literature, they pointed out that orthodontic treatment itself does not increase the incidence of periodontal pathologies. However, some scholars found oral hygiene procedures have a great impact on the periodontal status of orthodontic patients. Orthodontic treatment is sometimes considered to be a predisposing factor for periodontal disease, because orthodontic appliances may prevent complete oral hygiene procedures and cause bacterial aggregation. However, some scholars believe that orthodontic treatment can be used as a causative factor for periodontal disease. The explanation for this viewpoint is that orthodontic devices may prevent complete oral hygiene procedures and cause an increase in bacterial aggregation $[7$, 34, 41, 42]. Some clinical and experimental studies have shown that when inflammation is not completely controlled, orthodontic treatment may also cause inflammatory response even in patients with good oral hygiene, thereby accelerating the development of periodontal damage and resulting in attachment loss $[43,44]$. The pros of the study includes flexibility, less time consumption and accessibility. The limitations of the study include a distinct ethnic group.

\section{Conclusion}

Within the limits of the study, it can be concluded that only $1.91 \%$ of patients using removable orthodontic appliances, had periodontitis. It was observed that more number of periodontitis patients belonged to the age group above 30 years. Further research studies with long-term follow ups in older age groups are required to periodically emphasise the importance of oral health in patients undergoing removable orthodontic treatment in order to maintain a healthy periodontium.

\section{Authors Contribution}

First author, sandhya performed the data collection by reviewing patient details, filtering required data, analysing and interpreting statistics and contributed to manuscript writing.

Second author, Dr. Nashra Kareem contributed to conception of study title, study design, analysed the collected data, statistics and interpretation and also critically revised the manuscript.

Third author, Dr. SenthilMuruganP participated in the study and revised the manuscript. All the three authors have discussed the results and contributed to the final manuscript.

\section{Acknowledgement}

This research was supported by saveetha dental college and hospital. We thank the department of Orthodontics and Periodontics, Saveetha Dental College for providing insight and expertise that greatly assisted this research.

\section{References}

[1]. Proffit WR, Fields HW.(1993)Contemporary Orthodontics. Mosby Elsevier Health Science;. 688 p.

[2]. Schott TC, Meyer-Gutknecht H, Mayer N, Weber J, Weimer K. A comparison between indirect and objective wear-time assessment of removable 
orthodontic appliances. Eur J Orthod. 2017 Apr 1;39(2):170-175.Pubmed PMID: 27030283

[3]. Ong MA, Wang HL, Smith FN. Interrelationship between periodontics and adult orthodontics. J. Clin. Periodontol. 1998 Apr;25(4):271-7.

[4]. Eliasson LÅ, Hugoson A, Kurol J, Siwe H. The effects of orthodontic treatment on periodontal tissues in patients with reduced periodontal support. Eur. J. Orthod. 1982 Feb 1;4(1):1-9.

[5]. Alstad S, Zachrisson BU. Longitudinal study of periodontal condition associated with orthodontic treatment in adolescents. Am J Orthod. 1979 Sep;76(3):277-86.Pubmed PMID: 290273.

[6]. Miethke RR, Vogt S. A comparison of the periodontal health of patients during treatment with the Invisalign system and with fixed orthodontic appliances. J OrofacOrthop. 2005 May;66(3):219-29.Pubmed PMID: 15959635.

[7]. Ristic M, Svabic MV, Sasic M, Zelic O. Clinical and microbiological effects of fixed orthodontic appliances on periodontal tissues in adolescents. OrthodCraniofac Res. 2007 Nov;10(4):187-95.

[8]. Gomes SC, Varela CC, da Veiga SL, Rösing CK, Oppermann RV. Periodontal conditions in subjects following orthodontic therapy. A preliminary study. Eur J Orthod. 2007 Oct;29(5):477-81.Pubmed PMID: 17693428.

[9]. vanGastel J, Quirynen M, Teughels W, Coucke W, Carels C. Longitudinal changes in microbiology and clinical periodontal variables after placement of fixed orthodontic appliances. J Periodontol. 2008 Nov;79(11):2078-86. Pubmed PMID: 18980516

[10]. Socransky SS, Haffajee AD. The bacterial etiology of destructive periodontal disease: current concepts. J. Periodontol. 1992 Apr;63:322-31.

[11]. Lu H, Tang H, Zhou T, Kang N. Assessment of the periodontal health status in patients undergoing orthodontic treatment with fixed appliances and Invisalign system: A meta-analysis. Medicine (Baltimore). 2018 Mar;97(13):e0248.Pubmed PMID: 29595680

[12]. Pender N. Aspects of oral health in orthodontic patients. Br. J. Orthod. 1986 Apr 1;13(2):95-103.

[13]. Pellegrino M, Lucchese A, Montini E, Liguori A, Manuelli M. The effect of removable orthodontic appliances on oral microbiota: systematic review.

[14]. Miethke RR, Brauner K. A Comparison of the periodontal health of patients during treatment with the Invisalign system and with fixed lingual appliances. J OrofacOrthop. 2007 May;68(3):223-31.Pubmed PMID: 17522806.

[15]. Jervøe-Storm PM, Koltzscher M, Falk W, Dörfler A, Jepsen S. Comparison of culture and real-time PCR for detection and quantification of five putative periodontopathogenic bacteria in subgingival plaque samples. J ClinPeriodontol. 2005 Jul;32(7):778-83.Pubmed PMID: 15966886.

[16]. Lau L, Sanz M, Herrera D, Morillo JM, Martín C, Silva A. Quantitative real-time polymerase chain reaction versus culture: a comparison between two methods for the detection and quantification of Actinobacillusactinomycetemcomitans, Porphyromonasgingivalis and Tannerellaforsythensis in subgingival plaque samples. J ClinPeriodontol. 2004 Dec;31(12):1061-9. Pubmed PMID: 15560806.

[17]. Jordan C, LeBlanc DJ. Influences of orthodontic appliances on oral populations of mutans streptococci. Oral MicrobiolImmunol. 2002 Apr;17(2):6571.Pubmed PMID: 11929551.

[18]. Thamaraiselvan M, Elavarasu S, Thangakumaran S, Gadagi JS, Arthie T. Comparative clinical evaluation of coronally advanced flap with or without platelet rich fibrin membrane in the treatment of isolated gingival recession. J Indian SocPeriodontol. 2015 Jan;19(1):66.

[19]. Ramesh A, Varghese SS, Doraiswamy JN, Malaiappan S. Herbs as an antioxidant arsenal for periodontal diseases. J IntercultEthnopharmacol. 2016 Jan 27;5(1):92-6.Pubmed PMID: 27069730.

[20]. Varghese SS, Thomas H, Jayakumar ND, Sankari M, Lakshmanan R. Estimation of salivary tumor necrosis factor-alpha in chronic and aggressive periodontitis patients. ContempClin Dent. 2015 Sep;6(Suppl 1):S152-6. Pubmed PMID: 26604566.

[21]. Avinash K, Malaippan S, Dooraiswamy JN. Methods of Isolation and Characterization of Stem Cells from Different Regions of Oral Cavity Using Markers: A Systematic Review. Int J Stem Cells. 2017 May 30;10(1):12-20. Pubmed PMID: 28531913.

[22]. Panda S, Jayakumar ND, Sankari M, Varghese SS, Kumar DS. Platelet rich fibrin and xenograft in treatment of intrabony defect. ContempClin Dent. 2014 Oct;5(4):550-4.Pubmed PMID: 25395778.

[23]. Mootha A, Malaiappan S, Jayakumar ND, Varghese SS, Toby Thomas J. The Effect of Periodontitis on Expression of Interleukin-21: A Systematic Review. Int J Inflam. 2016;2016:1-8.Pubmed PMID: 26998377.

[24]. Khalid W, Vargheese SS, Lakshmanan R, Sankari M, Jayakumar ND. Role of endothelin-1 in periodontal diseases: A structured review. Indian J Dent Res.
2016 May-Jun;27(3):323-33.Pubmed PMID: 27411664

[25]. Khalid W, Varghese SS, Sankari M, Jayakumar ND. Comparison of Serum Levels of Endothelin-1 in Chronic Periodontitis Patients Before and After Treatment. J ClinDiagn Res. 2017 Apr;11(4):ZC78-ZC81.Pubmed PMID: 28571268.

[26]. Ramesh A, Varghese SS, Jayakumar ND, Malaiappan S. Chronic obstructive pulmonary disease and periodontitis-unwinding their linking mechanisms. J. Oral Biosci. 2016 Feb 1;58(1):23-6.

[27]. Kavarthapu A, Thamaraiselvan M. Assessing the variation in course and position of inferior alveolar nerve among south Indian population: A cone beam computed tomographic study. Indian J Dent Res. 2018 JulAug;29(4):405-409.Pubmed PMID: 30127186.

[28]. Ramesh A, Ravi S, Kaarthikeyan G. Comprehensive rehabilitation using dental implants in generalized aggressive periodontitis. I Indian SocPeriodontol. 2017 Mar-Apr;21(2):160-163.Pubmed PMID: 29398863.

[29]. Ramesh A, Vellayappan R, Ravi S, Gurumoorthy K. Esthetic lip repositioning: A cosmetic approach for correction of gummy smile - A case series. J Indian SocPeriodontol. 2019 May-Jun;23(3):290-294.Pubmed PMID: 31143013.

[30]. Gajendran PL, Parthasarathy H, Tadepalli A. Comparative evaluation of cathepsin $\mathrm{K}$ levels in gingival crevicular fluid among smoking and nonsmoking patients with chronic periodontitis. Indian J Dent Res. 2018 SepOct;29(5):588-593.Pubmed PMID: 30409937.

[31]. Ravi S, Malaiappan S, Varghese S, Jayakumar ND, Prakasam G. Additive Effect of Plasma Rich in Growth Factors With Guided Tissue Regeneration in Treatment of Intrabony Defects in Patients With Chronic Periodontitis: A Split-Mouth Randomized Controlled Clinical Trial. J Periodontol. 2017 Sep;88(9):839-845.Pubmed PMID: 28474968.

[32]. Priyanka S, Kaarthikeyan G, Nadathur JD, Mohanraj A, Kavarthapu A. Detection of cytomegalovirus, Epstein-Barr virus, and Torque Teno virus in subgingival and atheromatous plaques of cardiac patients with chronic periodontitis. J Indian SocPeriodontol. 2017 Nov-Dec;21(6):456-460.Pubmed PMID: 29551863

[33]. Sköld-Larsson K, Yucel-Lindberg T, Twetman S, Modéer T. Effect of a triclosan-containing dental gel on the levels of prostaglandin I 2 and interleukin-1beta in gingival crevicular fluid from adolescents with fixed orthodontic appliances. ActaOdontol Scand. 2003 Aug;61(4):193-6.Pubmed PMID: 14582585.

[34]. Alexander SA. Effects of orthodontic attachments on the gingival health of permanent second molars. Am J OrthodDentofacialOrthop. 1991 Oct;100(4):337-40.Pubmed PMID: 1927984.

[35]. Atack NE, Sandy JR, Addy M. Periodontal and microbiological changes associated with the placement of orthodontic appliances. A review. J Periodontol. 1996 Feb;67(2):78-85.Pubmed PMID: 8667140.

[36]. Tuncer AV, Baylas H. ÇeşitliOrtodontikApareyTaşıyanBireylerin Periodontal Dokularınınİncelenmesi. Turk J Orthod.1990;3:13-8.

[37]. Artun J, Spadafora AT, Shapiro PA, McNeill RW, Chapko MK. Hygiene status associated with different types of bonded, orthodontic canine-to-canine retainers. A clinical trial. J ClinPeriodontol. 1987 Feb;14(2):89-94.Pubmed PMID: 3469225.

[38]. Anggraeni R, Malik I, Hendiani I. Gingival and oral hygiene conditions in patients with fixed orthodontic appliance wearers. PJoD. 2011 Jul 31;23(2).

[39]. Karkhanechi M, Chow D, Sipkin J, Sherman D, Boylan RJ, Norman RG, et al. Periodontal status of adult patients treated with fixed buccal appliances and removable aligners over one year of active orthodontic therapy. Angle Orthod. 2013 Jan;83(1):146-51.Pubmed PMID: 22725616.

[40]. McGuinness N. The effects of orthodontic therapy on periodontal health: a systematic review of controlled evidence. Orthodontic.2009;2: 83.

[41]. Paolantonio M, Festa F, di Placido G, D'Attilio M, Catamo G, Piccolomini R. Site-specific subgingival colonization by Actinobacillusactinomycetemcomitans in orthodontic patients. Am J OrthodDentofacialOrthop. 1999 Apr;115(4):423-8.Pubmed PMID: 10194288.

[42]. Sallum EJ, Nouer DF, Klein MI, Gonçalves RB, Machion L, Sallum AW, et al. Clinical and microbiologic changes after removal of orthodontic appliances. Am J Orthod DentofacialOrthop. 2004 Sep 1;126(3):363-6.

[43]. Artun J, Urbye KS. The effect of orthodontic treatment on periodontal bone support in patients with advanced loss of marginal periodontium. Am J OrthodDentofacialOrthop. 1988 Feb;93(2):143-8.Pubmed PMID: 3422529.

[44]. Wennström JL, Stokland BL, Nyman S, Thilander B. Periodontal tissue response to orthodontic movement of teeth with infrabony pockets. Am J OrthodDentofacialOrthop. 1993 Apr;103(4):313-9.Pubmed PMID: 8480696. 